NBER WORKING PAPER SERIES

\author{
RETURNS TO SENIORITY IN \\ UNION AND NONUNION JOBS: \\ A NEW LOOK AT THE EVIDENCE
}

\author{
Katharine G. Abraham \\ Henry S. Farber
}

Working Paper No 2368
NATIONAL BUREAU OF ECONOMIC RESEARCH 1050 Massachusetts Avenue Cambridge, MA 02138
August 1987

The authors thank Joe Altonji for providing us with the data used in this study, Jim Powell for providing valuable econometric advice, and Leslie Sundt and Kelly Eastman for providing able research assistance. Farber received support from the National Science Foundation. The views expressed here are those of the authors and should not be attributed to the trustees, officers of staff members of the institutions with which they are affiliated. The research reported here is part of the NBER's research program in Labor Studies. Any opinions expressed are those of the authors and not those of the National Bureau of Economic Research. 


\section{Returns to Seniority in Union and Nonunion Jobs: \\ A New Look at the Evidence}

\section{$\underline{\text { ABSTRACT }}$}

One of the most prominent features of U.S. unionism is the key role played by seniority. However, in cross-sectional data, the positive association between seniority and earnings is typically much stronger for nonunion workers than for union workers. This finding has puzzled previous researchers, since it seems inconsistent with the generalization that seniority is more important in the union sector than in the nonunion sector. We show that standard estimates of the return to seniority are likely to be biased upward and argue that the bias is likely to be larger in the nonunion sector than in the union sector. Corrected estimates imply that the return to seniority is, in fact, larger in the union sector than in the nonunion sector.

Katharine G. Abraham The Brookings Institution 1778 Massachusetts Avenue, NW washington, DC 20036
Henry S. Farber Department of Economics MIT

Cambridge, MA 02139 


\section{Introduction}

A prominent feature of U.S. unionism is the key role played by seniority. As early as the 1920's and 1930's, replacing foreman's discretion with a seniority-based reward structure was an important focus of the emerging union movement. 1 Modern theories of union behavior emphasize the strength of senior workers' influence on union objectives (Farber, 1978; Blair and Crawford, 1984; Freeman and Medoff, 1984; Farber, 1986). Recent evidence indicates that seniority is indeed substantially more important in both layoffs and promotions under collective bargaining than in its absence (Abraham and Medoff, 1984, 1985). The major exception to the generalization that seniority is more important in the union sector than in the nonunion sector is the finding, replicated by a number of researchers using different data sets, that the slope of the seniority-earnings profile in a cross-section is steeper for nonunion workers than for union workers. ${ }^{2}$

In this study, we challenge the finding that the returns to seniority are greater among nonunion workers than among union workers. Elsewhere (Abraham and Farber, 1987), we argue that standard cross-section estimates of the returns to seniority are biased upwards, and we provide evidence that this bias is quite important for nonunion workers. Here, we argue that this bias is larger for nonunion workers than for union workers and that the true returns to seniority are larger among union workers than among nonunion workers. In the next section we present a discussion of the sources of bias

1. Slichter (1941) offers an insightful discussion of union attitudes towards seniority rules. See also Gersuny (1981).

2. Representative studies include Leigh (1978), Borjas (1979), and Pfeffer and Ross (1980), all using the National Longitudinal Survey of Mature Men; Farber (1983) using the Quality of Employment Survey; Polachek (1983) using the Panel Study of Income Dynamics; and Mellow (1983) using the May 1979 Current Population Survey. Many of these studies are summarized in Lewis (1986). 
in the standard estimates of the return to seniority, and we discuss why the bias is expected to be larger for nonunion workers in section III.

In section IV we develop two alternative approaches to deriving consistent estimates of the return to seniority. Both approaches depend on a measure of completed job duration that we construct using data from the Michigan Panel Study of Income Dynamics (PSID) based on the estimation of separate Weibull proportional hazards models for the union and nonunion sectors. The construction of these job duration measures is described in section $V$ of the paper. Section VI contains the paper's central results regarding the estimation of separate earnings functions for union and nonunion males in blue-collar jobs from the PSID.

The results are in line with our expectations. In standard cross section earnings equations fit for samples of blue collar workers, the estimated return to seniority is larger for the nonunion group than for the union group. However, once the upward bias in these standard estimates is taken into account, we find that the returns to seniority are larger for union blue collar workers than for nonunion blue collar workers.

\section{Bias in Cross-Section Earnings Functions}

We turn now to a simple model of the sources of bias in cross-section estimates of the return to seniority. Such bias may arise from unmeasured individual differences in earnings and/or from unmeasured job/match differences in earnings. Individual heterogeneity will cause an upward bias in the estimated return to seniority if more able individuals both earn higher wages and stay longer on their jobs. Job/match heterogeneity will cause an upward bias if workers on good jobs or in good matches both earn more and stay longer on their jobs. The model illustrates the contribution of three factors to the magnitude of the upward bias in the estimated return to seniority. 
These factors are 1) the degree to which ability is rewarded with higher pay, 2) the variance in ability in the sample population, and 3 ) the variance in the job/match component in earnings.

Suppose that the earnings of a particular worker on a particular job at a particular point in time can be written:

(1) $\quad \ln W_{i j t}=B_{1} S_{i j t}+B_{2} \operatorname{EXP}_{i j}+\delta A_{i}+\mu_{i j}+n_{i j t}$

where

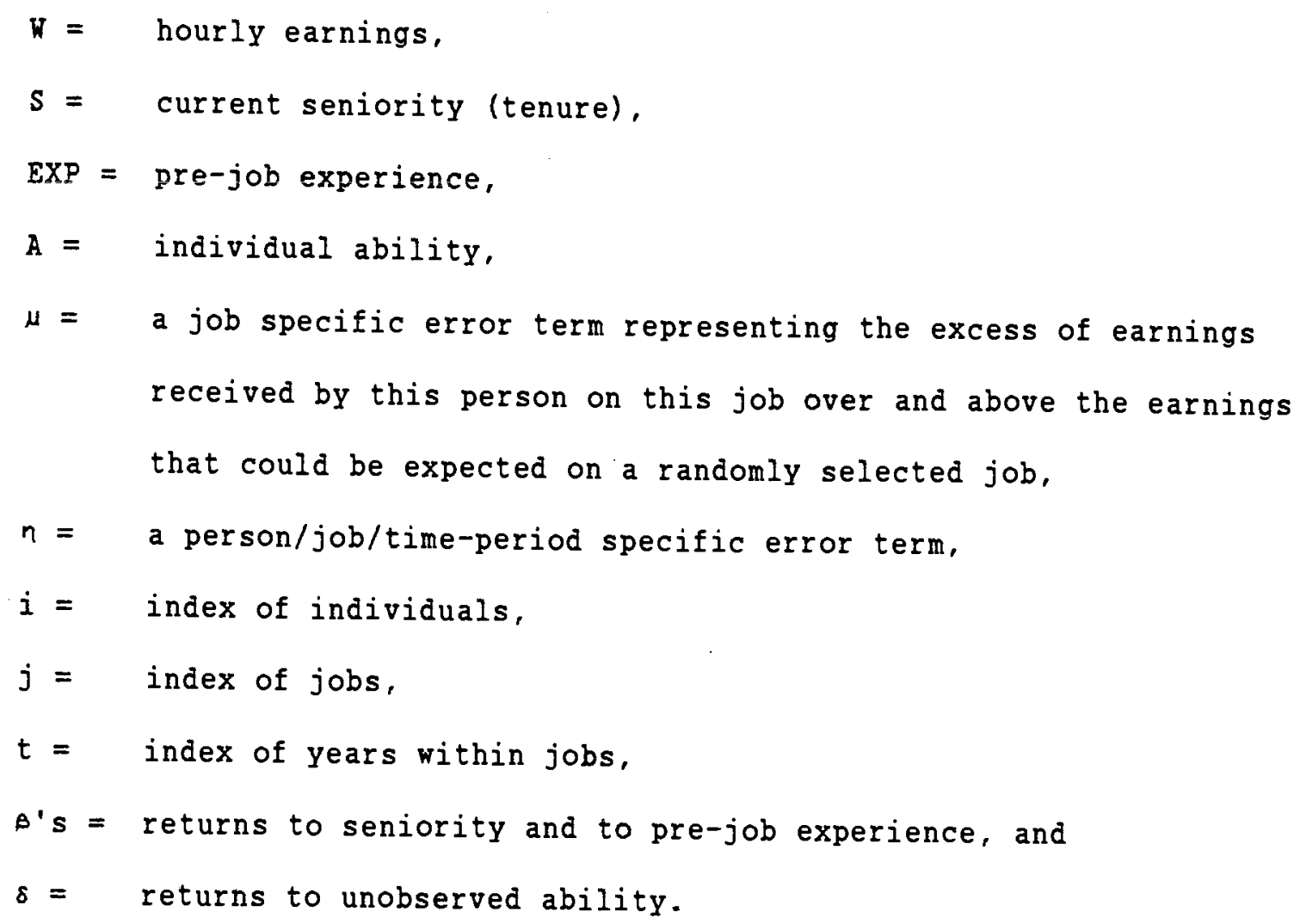

For simplicity of exposition, other factors that might influence earnings are omitted from the model and all variables are assumed to be measured as deviations from their means. In this formulation, $\mu_{i j}$ captures the net influence of two unobservables on hourly earnings: unobserved job quality and unobserved match quality. $A_{i}$ is assumed to be fixed over an individual's lifetime and $\mu_{i j}$ is assumed to be fixed over the course of a job. $A_{i}$ may be correlated with $S_{i} \mu_{i j}$ may be correlated with both $S$ and EXP. $A_{i}$ and $\mu_{i j}$ are 
assumed to be orthogonal to one another, and the error $n_{i j t}$ is assumed to be orthogonal to S, EXP, A and $\mu .^{3}$

In equation (1), ${ }_{2}$ represents the returns to experience due to accumulation of general human capital or simply to the passage of time in the labor market. Earnings are also likely to grow with experience because more experienced workers, having had more chances to search for and sample labor market opportunities, typically end up in better jobs and/or better matches. 4 This means that more experienced workers are likely to have higher $\mu_{i j}$ 's so that

$$
\text { (2) } \mu_{i j}=\alpha \overline{E X P} P_{i j}+\phi_{i j}
$$

where $\mu$ and EXP are as previously defined, $\alpha$ is a parameter that summarizes the relationship between $\mu$ and EXP, and $\phi_{i j}$ is the variation in $\mu$ not systematically related to EXP. Substituting into equation (1) yields:

$$
\text { (3) } \quad \ln W_{i j t}=\beta_{1} S_{i j t}+\left(\beta_{2}+\alpha\right) \operatorname{EXP} P_{i j}+\delta A_{i}+\phi_{i j}+n_{i j t}
$$

where $\beta_{1}$ is the total return to seniority and $\beta_{2}+\alpha$ is the total return to pre-job experience. The net return to seniority is appropriately defined as the excess of growth in earnings on a given job over and above the total returns to general labor market experience, or $\theta_{1}-\left(\theta_{2}+\alpha\right)$.

In practice, earnings functions are usually estimated using crosssection data where neither $A_{i}$ nor $\mu_{i j}$ are observable. The earnings function as oroinarily implemented in a cross-section can be rewritten as:

(4) $\quad \ln _{i j t}=b_{1} s_{i j t}+b_{2} \operatorname{EXP}_{i j}+v_{i j t}$ ' where $v_{i j t}$ is the estimating equation error. Note that both the personspecific component of the error $\left(\delta A_{i}\right)$ and the job/match specific component of the error $\left(\phi_{i j}\right)$ are omitted from the equation.

3. This model is a generalization of the model presented in Abraham and Farber (1987).

4. See and Topel (1985) and Abraham and Farber (1987). 
How does omitting these person and job/match error components from the earnings equation affect the estimated value of the net return to seniority, $\theta_{1}-\left(\theta_{2}+\alpha\right)$ ? To answer this question, we need to impose more structure on the interrelationships among seniority, experience, job duration, $A_{i}$ and $\mu_{i j}$. Suppose that the completed duration of jobs is positively related to both ${ }_{i}$ and $\mu_{i j}$ and that the following relationship holds:

(5) $D_{i j}=\gamma_{1} A_{i}+\gamma_{2} \mu_{i j}+\varepsilon_{i j}$ '

where $D_{i j}$ is the completed length of the current job, $A_{i}$ and $\mu_{i j}$ are as defined above, and the $\gamma^{\prime} s$ are parameters that summarize the relationships of $D$ with $A$ and $\mu$. The parameter $\gamma_{1}$ will be positive to the extent that more able workers are on longer duration jobs, and the parameter $\gamma_{2}$ will be positive to the extent that workers in "good" jobs or good matches are on longer duration jobs. The random component, $\varepsilon_{i j}$, captures the variation in completed job duration that cannot be linked to variation in worker quality or to variation in the earnings advantage associated with job/match quality. 5 Substituting from equation (2),

(6) $D_{i j}=\gamma_{1} A_{i}+\alpha \gamma_{2} \operatorname{EXP}_{i j}+\gamma_{2} \phi_{i j}+\varepsilon_{i j}$,

Holding initial experience constant, completed job duration is positively related to both $A_{i}$ and $\Phi_{i j}{ }^{\circ}$

If each year of any given job is equally likely to be represented in a cross-section of observations, then on average the observed seniority on the job will be halfway through the job. More formally

(7) $E\left(S_{i j t}\right)=1 / 2 * D_{i j}$.

and

(8) $s_{i j t}=1 / 2 * D_{i j}+\varepsilon_{i j t}$

5. It should be emphasized that neither equation (4) nor equation (5) is a structural equation. Both are intended simply to summarize relationships expected in cross-section data. 
where $\varepsilon_{i j t}$ is a random variable with zero mean. The distribution of $\varepsilon_{i j t}$ will vary depending upon the completed length of the job, but $s_{i j t}$ is uncorrelated with $\mu_{i j}$, with $D_{i j}$ and with $\operatorname{EXP}_{i j}$.

Using these relationships, it is straightforward to show that

$$
\begin{aligned}
E\left(b_{1}\right)=\beta_{1}+(1 / 2) * & \operatorname{var}\left(\operatorname{EXP}_{i j}\right) \star \\
& {\left[\delta \star \gamma_{1} \star \operatorname{var}\left(\AA_{i}\right)+\gamma_{2} \star \operatorname{var}\left(\phi_{i j}\right)\right] *\left(1 / \operatorname{DET}_{1}\right) }
\end{aligned}
$$

and that

$$
\text { (10) } \begin{aligned}
E\left(b_{2}\right)=\left(\theta_{2}+\alpha\right)-b_{\operatorname{EXP}, S} \star(1 / 2) \star \operatorname{var}\left(\operatorname{EXP}_{i j}\right) \star \\
\\
{\left[\delta \star \gamma_{1} \star \operatorname{var}\left(A_{i}\right)+\gamma_{2}{ }^{\star} \operatorname{var}\left(\phi_{i j}\right)\right] *\left(1 / \operatorname{DET}_{1}\right) }
\end{aligned}
$$

where bEXP, $S$ is the coefficient obtained from a regression of EXP on $S$ (which is expected to be positive), DET ${ }_{1}$ is the determinant of the $X$ 'X matrix containing cross-products of seniority and experience, and the other terms are as previously defined. Thus, the estimated total return to seniority is biased upwaras and the estimated total return to experience is correspondingly biased downwards. Both the upward bias in the estimated total return to seniority and the downward bias in the estimated total return to experience contribute to an upward bias in the estimated net return to seniority, $b_{1}-$ $\mathrm{b}_{2}$

The formal model, and in particuiar equations (9) and (10), highlight several factors that may contribute to greater upward bias in the estimated return to seniority, other things equal. First, assuming that $\gamma_{1}$ is positive, the bias will be larger where the variance in unobserved ability $\left(\operatorname{var}\left(\mathbb{A}_{i}\right)\right.$ ) is larger. Second, again assuming that $\gamma_{1}$ is positive, the bias will be larger where the reward to unobserved ability $(\delta)$ is larger. Third, the bias will be larger where the variance in the job/match component of earnings that is not systematically related to pre-job experience $\left(\operatorname{var}\left(\phi_{i j}\right)\right)$ is larger. Note that

$$
\operatorname{var}\left(\phi_{i j}\right)=\operatorname{var}\left(\mu_{i j}\right)-\alpha^{2} \star \operatorname{var}\left(\operatorname{EXP}_{i j}\right) \text {. }
$$


If $\alpha^{2} \operatorname{var}\left(\operatorname{EXP}_{i j}\right)$ is similar across two samples, then the difference in the variance of $\phi$ across the samples will be approximately equal to the difference in the variance of $\mu$.

III. Why is the Bias Likely to be Larger in the Nonunion Sector?

Available evidence pertaining to returns to ability, heterogeneity in ability, and heterogeneity in the job/match component of earnings among union versus nonunion workers provides grounds for believing that the union seniority coefficient is less seriously upward biased than the nonunion seniority coefficient.

First, it is likely that the rewards to unobserved ability are lower in the union sector than in the nonunion sector. Numerous observers have noted the importance of single/standard rate policies and automatic progression policies in union wage setting (for example, the Vebbs, 1920; and slichter, Healy and Livernash, 1960). Using data from the Industry Wage Surveys carried out by the Bureau of Labor statistics (BLS), Freeman (1982) documents that within-establishment wage dispersion is lower in the union segment than in the nonunion segment of the industries for which data are available. He also notes that explicit single rate and automatic progression policies account for much of this difference in wage dispersion for union as compared to nonunion establishments. Such policies leave little room to reward differences in workers' ability. Numerous other studies (e.g., Bloch and Kuskin, 1976; Lewis, 1986) using data on individuals have established that skill differentials and educational differentials in wages are lower among unionized workers than among nonunion workers. While these studies pertain only indirectly to the rewards to unobservable differences in ability, they suggest strongly that the rewards $(\delta)$ associated with these differences are lower among union workers. To the extent that this is true, the bias in estimated 
seniority coefficients will be less for samples of union workers.

Next, it is plausible that there is less heterogeneity in ability among union workers than among nonunion workers. Abowd and Farber (1982) and Farber (1983) develop and test a queuing model of union status determination. They hypothesize that "more skilled workers would be less likely to desire a union job while union employers would be more likely to want to hire more skilled workers" (Abowd and Farber, 1982, p. 367), and their empirical findings are generally supportive of the model. To the extent that unobserved ability is an important factor in both worker selection and employer selection, the dispersion of ability among union workers will be lower than the dispersion of ability among nonunion workers. Assuming that more able workers are also more stable, lower dispersion in ability $\left(\operatorname{var}\left(A_{i}\right)\right)$ for union workers means less upward bias in estimated seniority coefficients for samples of union workers.

Finally, there is reason to suspect that the variation in the job/match component of earnings will be lower across union jobs than across nonunion jobs. Institutional labor economists have long recognized that unions strive to standardize rates across establishments, at least within broad sectors (see Slichter, Healy and Livernash (1960)). Freeman (1982) offers evidence that dispersion in average wages across union establishments in an industry does tend to be lower than the dispersion in wages across nonunion establishments in the same industry. In addition, the same forces limiting employers' power to reward higher ability workers would also limit their power to pay higher wages to workers who are especially well suited to a particular job, thereby reducing the importance of match-specific (as opposed to job-specific) effects. To the extent that the variation in that part of the job/match component of earnings not systematically related to experience $\left(\operatorname{var}\left(\phi_{i j}\right)\right)$ is lower across union jobs than across nonunion jobs, this too will contribute to lower bias in the estimated return to seniority in cross-section earnings 
equations fit for samples of union workers.

Further evidence concordant with the above hypotheses is provided by the various studies which conclude that the dispersion of wages is lower in the union sector than in the nonunion sector, even after controlling for the influence of observable individual characteristics. 6

These arguments for why we might expect less bias in the estimated return to seniority for union workers than for nonunion workers assume that other things are equal across the two sectors. We have no a priori reason to expect that $\gamma_{1}, \gamma_{2}, b_{E X P}, s^{\prime} \operatorname{var}(E X P)$, or the ratio of $\operatorname{var}(\operatorname{EXP})$ to DET $_{1}$ should aiffer systematicaliy between the union and the nonunion sectors. We cannot simply compute the relative biases in the estimated net returns to seniority in union and nonunion earnings functions using equations (9) and (10) since much of the information on unobservables that would be needed is unavailable. However, we have developed methods for computing corrected estimates of the seniority coeficients in cross-section earnings equations.

IV. Corrected Cross-section Estimates of the Return to Seniority

One approach to correcting the equation (4) estimates of the returns to seniority and to experience is to find an appropriate instrument for the seniority variable. Equation (8) suggests a suitable instrument: 'sjt' which equals $s_{i j t}-1 / 2 * D_{i j}$. By construction, $\xi_{i j t}$ is correlated with seniority but uncorrelated with completed duration and thence uncorrelated with the omitted individual and job/match components in the earnings equation. The instrumental variables estimator of $b_{1}$ is a consistent estimator of $\beta_{1}$ and the instrumental variables estimator of $b_{2}$ is a consistent estimator of $\beta_{2}+\alpha$.

6. These studies include Hyclak (1979), Freeman (1980) and Hirsch (1982). 
The preceding assumes that the expected value of current seniority in a cross-section is indeed just equal to half completed job duration. This assumption is stronger than necessary and may not be precisely correct. For example, in a growing population, there will likely be more people near the start of their jobs than near the end. More generaily, using the residual from the regression of seniority on completed job duration as an instrument for seniority yields consistent estimates of $B_{1}$ and $B_{2}+\alpha$. By construction, this residual is uncorrelated with completed duration and correlated with seniority. ${ }^{7}$

An appealing alternative approach to correcting the bias in the estimated seniority coefficient in a cross-section earnings equation is to control explicitly for the completed length of the job. We term this the "augmented OLS" approach. The seniority coefficient in equation (4) is upward biased only because both $A_{i}$ and $\Phi_{i j}$ are related to how long a job ends up lasting, and workers in jobs that end up lasting a long time tend to have higher current seniority when we observe them in a cross-section. Augmenting equation (4) by adding $D_{i j}$ as an explanatory variable yields the following specification:

(12) $\ln w_{i j t}=\bar{b}_{1} s_{i j t}+\bar{b}_{2} \operatorname{EXP}_{i j}+\bar{b}_{3} D_{i j}+\omega_{i j t}$. The seniority coefficient in equation (12), $\bar{b}_{1}$, is an unbiased estimator of $B_{1}$. The experience coefficient has expectation:

$$
\begin{aligned}
& \text { (13) } E\left(\bar{b}_{2}\right)=B_{2}+\alpha-b_{E X P, D}{ }^{\star} \operatorname{var}\left(E_{i j}\right) * \\
& {\left[\delta \gamma_{1}\left(\operatorname{varA_{i}}\right)+\gamma_{2} \operatorname{var}\left(\phi_{i j}\right)\right] *\left[1 / D E T T_{2}\right] \text {, }}
\end{aligned}
$$

where $b_{\text {EXP,D }}$ is the coefficient obtained from a regression of EXP on $D$ (which

7. For more details in the context of a simpler model, see Abraham and Farber (1987). Altonji and shakotko (1987) present a related instrumental variables approach to estimating the returns to seniority. 
expected to be positive), DET 2 equals the determinant of the $2 \times 2$ matrix containing cross-products of EXP and $D$, and the other terms are as previously defined. So long as workers with more pre-job experience tend to stay longer in their positions, $\bar{b}_{2}$ is a downward biased estimate of $A_{2}+\alpha$. This, in . turn, implies that $\bar{b}_{1}-\bar{b}_{2}$ is an upward biased estimate of the net return to seniority. ${ }^{8}$ The augmented ols procedure has the advantage that it permits direct examination of the relationship between completed job duration and earnings, both on average and over the course of the job.

Using the identity that links total experience with pre-job experience and seniority $\left(\operatorname{EXP}_{i j t}=\operatorname{EXP}_{i j}+s_{i j t}\right)$ and ignoring second order terms, valid inferences regarding the net return to seniority can be drawn from an earnings function specification that includes either pre-job experience or total experience along with seniority. Where pre-job experience is used, the net return to seniority $\left(\beta_{1}-\left[\beta_{2}+\alpha\right]\right)$ is calculated as the difference between the coefficient on seniority and the coefficient on pre-job experience. Where total experience is used, the net return to seniority is simply the coefficient on seniority. To facilitate discussion regarding the net return to seniority, we proceed from here using total experience. ${ }^{9}$

In the empirical analysis that follows, we develop a measure of completed job duration using longitudinal data and use this measure in the two

8. In the samples we examine, the instrumental variables procedure and the alternative procedure of adding completed job duration to the earnings equation yield almost identical estimates of the net return to seniority. This implies that, in these samples, the bias in the estimated total return to experience and the resulting bias in the estimated net return to seniority are
quite small. See section VI.

9. For the instrumental variables estimator, this requires the minor modification that total experience (and its square, if included) must be instrumented for along with seniority. The natural additional instruments are pre-job experience (and its square). In a model without squared terms, the IV estimator of the specification using pre-job experience and the IV estimator using total experience with pre-job experience as an additional instrument yield identical estimates of the underlying parameters. 
ways just described to estimate "corrected" earnings functions for samples of union and nonunion blue collar workers.

\section{v. Estimating Completed Job Duration}

The first step in implementing the analysis just described is to derive a measure of completed job duration. Clearly, a data set suitable for this task must follow individual workers over time so that one can observe how long the jobs they hold ultimately last. The data set should also have information on the individual workers' characteristics, including their union status, and their wages/earnings. The Michigan Panel Study of Income Dynamics (PSID) satisfies these requirements and is used in the empirical analysis. Unfortunately, even in a long panel like the PSID, there are many jobs which do not end by the date at which the individual is last observed. Some procedure must be used to impute completed durations to these jobs.

We take the approach of estimating a parametric model of job duration that accounts for the censoring of duration in those jobs for which the end is not observed. This model is then used to compute an estimate of the expected completed job duration conditional on the job lasting at least as long as the last observed seniority level. In the estimation of the earnings function, this estimate is used as the measure of completed job duration for the censored spelis. The actual completed job duration is used for jobs for which the end is observed. This procedure has the advantage of using all available information on job duration.

\section{A. The Jobs Sample}

All of the subsequent analysis is performed using data for male household heads aged 18 to 60 who participated in the PSID. 10 we used only

10. Unfortunately, the design of the PSID precludes meaningful examination 
observations from the random national sample portion of the PSID (the socalled Survey Research Center or SRC subsample). Persons who were retired, permanently disabled, self-employed, employed by the government or residents of Alaska or Hawaii were excluded from the sample. Because we were concerned that different processes might govern seniority attainment and earnings in different broad occupational groups, we look exclusively at samples of blue collar workers. 11 In what follows, we center our discussion on results for two samples of workers: unionized blue collar workers and nonunionized blue collar workers. ${ }^{12}$ In order to be clear in the identification of union and nonunion jobs, observations on jobs for which the worker changed union status during the course of the job do not appear in either sample. ${ }^{13}$ In each year from 1968 through 1980 in which those individuals satisfying our selection criteria were household heads, information was available on number of years they had held their current job, number of years they had worked prior to taking the current job, years of education, race, marital status, disability status, occupation, industry, region and earnings. ${ }^{14}$

of females for the purposes of this study. This is because complete information is available only for household heacs, and, where households contain both male and female adults, the male is assumed to be the head by
default.

11. There were not enough white collar unionized workers to permit a meaningful analysis of white collar workers.

12. In some years unionization refers to union membership, and in other years to coverage by a collective bargaining agreement. Where both were available, collective bargaining agreement coverage was used.

13. In 371 jobs workers were coded nonunion in some years and union in others. If 1) at least two thirds of the observed years on one of these jobs were coded nonunion, 2) there were no runs of three or more years coded union, the entire job was considered a nonunion job and was included in the nonunion sample. An analogous decision rule lead to the assignment of some mixed jobs to the union sample. A total of 149 jobs could not be assigned to either group and were deleted altogether.

14. More details on the data file used in the analysis, and in particular on the construction of the seniority variable, can be found in Abraham and Farber (1987). We are grateful to Joe Altonji for making his data extract
from the PSID available to us. 
There are 767 jobs held by 551 individuals represented in the union blue collar sample and 1417 jobs held by 831 individuals represented in the nonunion blue collar sample. Our concern at this point is with ascertaining how long each of these jobs ultimately lasted.

Various characteristics of the jobs in each of the two samples are reported in Table 1. Variables that can change over time in an unpredictable fashion (e.g.. marital status, occupation) are assumed constant and measured at the first point the job is observed in the sample. The last observed seniority on a job is always considered to be the seniority at the last date the person is observed with an employer, whether or not the individual is still in a blue collar position at that date. 15

In the union blue collar sample, we observe the actual completed duration for 327 of 767 jobs, and in the nonunion blue collar sample, for 775 of 1417 jobs. Not surprisingly, a large proportion of the completed jobs are relatively short: 71 percent of the completed jobs in the union blue coliar sample and 85 percent of those in the nonunion blue collar sample lasted no more than three years. However, in both samples, there are a sizable number of completed jobs lasting 3 to 10 years and over 10 years. Longer jobs are more common among the still-in-progress jobs: 28 percent of the incomplete jobs in the union blue collar sample and 22 percent of the incomplete jobs in the nonunion blue collar sample had lasted more than 10 years as of the last date they were observed.

15. For example, if an individual 1) was observed on a single job for ten years running: 2) reported being a blue collar worker for the first five years and a professional employee for the next five years; and 3) reported having 13 years seniority in the last observed year, then the job would appear in our sample with a last observed seniority of 13 years. 
Table 1:

Selected Characteristics of Jobs Samples ${ }^{a}$

Proportion with

$\begin{array}{cc}\text { Union } & \text { Nonunion } \\ \text { Blue } & \text { Blue } \\ \text { Collar } & \text { Collar } \\ \text { ete Censored } & \text { Complete Censored }\end{array}$

years of tenure at

last date job

observed in range:

$T \leq 1$

$1<T \leq 3$

$3<T \leq 10$

T > 10

.526

.180

.211

.0826

.166
.143
.318
.373

.639

.215

.115

.213

$.0310 \quad .224$

\section{Mean [standard}

deviation] of:

\begin{tabular}{|c|c|c|c|c|}
\hline $\begin{array}{l}\text { Years of tenure } \\
\text { at last date } \\
\text { job observed }\end{array}$ & $\begin{array}{c}3.3 \\
{[4.9]}\end{array}$ & $\begin{array}{c}10.1 \\
{[9.4]}\end{array}$ & $\begin{array}{c}1.9 \\
{[3.2]}\end{array}$ & $\begin{array}{c}6.7 \\
{[8.1]}\end{array}$ \\
\hline $\begin{array}{l}\text { NYears of pre-job } \\
\text { experience }\end{array}$ & $\begin{array}{l}10.7 \\
9.3]\end{array}$ & {$\left[\begin{array}{l}11.0 \\
9.7]\end{array}\right.$} & $\begin{array}{r}9.8 \\
{[9.0]}\end{array}$ & $\begin{array}{r}11.8 \\
{[10.0]}\end{array}$ \\
\hline $\begin{array}{l}\text { (Years pre-job } \\
\text { experience) }\end{array}$ & $\begin{array}{c}202.0 \\
{[322.8]}\end{array}$ & $\begin{array}{c}214.2 \\
{[347.1]}\end{array}$ & $\begin{array}{c}175.7 \\
{[325.1]}\end{array}$ & $\begin{array}{l}238.5 \\
{[372.0]}\end{array}$ \\
\hline $\begin{array}{l}\text { Years of } \\
\text { education }\end{array}$ & $\begin{array}{c}11.3 \\
{[2.5]}\end{array}$ & $\begin{array}{c}11.3 \\
{\left[\begin{array}{c}2.2]\end{array}\right]}\end{array}$ & $\begin{array}{c}11.4 \\
{[2.3]}\end{array}$ & {$\left[\begin{array}{c}11.3 \\
2.6]\end{array}\right.$} \\
\hline
\end{tabular}

Proportion:

$\begin{array}{lllll}\text { Nonwhite } & .104 & .136 & .139 & .137 \\ \text { Married } & .890 & .898 & .823 & .872 \\ \text { Disabled } & .092 & .068 & .076 & .114 \\ \text { Foreman, craft } & .355 & .430 & .421 & .461 \\ \text { Oper,labor } & .645 & .570 & .579 & .539\end{array}$

Number of observations

$327 \quad 440 \quad 675$

axcept for tenure and years of previous experience, all variables are reported as of the first year the job was observed. Previous experience was computed as the difference between reported experience in the first year the job was observed and seniority at that point. 


\section{B. Specification of the Job Duration Model}

In order to use completed job duration as an earnings equation control variable, we need a method of determining the expected completed duration of the incomplete jobs. We specify and estimate a parametric model of completed job duration for each sector, and then we use the estimated parameters to predict the expected completed length of jobs still in progress as of the last date we observe them.

The proportional hazard Weibull specification serves as the basis of the estimation reported here. In that specification, the probability that a job has completed duration (D) greater than or equal to $T$ is

(14) $\operatorname{Pr}(D Z T)=\exp \left[-\lambda T^{\alpha}\right]$ where $\alpha$ is a positive parameter. The proportional hazard assumption is that the baseline hazard is

$$
\text { (15) } \lambda=e^{-Z \gamma} \text {, }
$$

where $Z$ is a vector of observable individual characteristics hypothesized to affect job duration and $\gamma$ is a vector of parameters. The separation hazard associated with this distribution is:

(16) $H(t)=\lambda \alpha t^{(\alpha-1)}$

If the parameters of a Weibull duration model are estimated, there is some ambiguity in the interpretation of the estimate of $\alpha$. The obvious interpretation is that the estimated value of $\alpha$ indicates "true" duration dependence. An alternative interpretation is that the estimate of $\alpha$ is biased downward by unmeasured heterogeneity across individuals, jobs and/or matches. For the purposes of this study, we are not interested in distinguishing between true and spurious duration dependence. We are simply interested in estimating a parametric model of completed job duration that is flexible enough to make allowance for both true duration dependence and unmeasured heterogeneity in hazards. While we could specify a particular distribution 
for the unobserved heterogeneity in the hazard along with the Weibull form of duration dependence, it is well known that there are problems with robustness of the estimates of heterogeneity and duration dependence with regard to changes in the assumed distributions in models of this sort. ${ }^{16}$ We take the approach of estimating a simple Weibull model of completed job duration without any explicit representation for unmeasured heterogeneity.

The contribution to the likelihood function made by a completed job is the probability-density that the job lasted exactly $S_{f}$ years given that the job lasted at least $s_{0}$ years. ${ }^{17}$ Given a Weibull distribution for duration, this is

$$
\operatorname{Pr}\left(D=S_{f} \mid D>S_{0}\right)=\lambda \alpha S_{f}^{\alpha-1} \exp \left[-\lambda\left(S_{f}^{\alpha}-S_{0}^{\alpha}\right)\right] \text {. }
$$

Similarly, the contribution to the likelihood function made by a job with a censored duration is the probability that the job lasted more than $\mathrm{s}_{f}$ years given that the job lasted at least $s_{0}$ years. This is

$$
\operatorname{Pr}\left(D \geq S_{f} \mid D>S_{0}\right)=\exp \left[-\lambda\left(S_{f}^{\alpha}-S_{0}^{\alpha}\right)\right] \text {. }
$$

The log-likelihood function is formed from these probabilities as

$$
\begin{aligned}
& \text { (19) } \ln (L)= \sum_{j}\left(C_{j} \ln \operatorname{Pr}\left(D_{j} 2 S_{f j} \mid D_{j}>S_{0 j}\right)+\right. \\
&\left.\left(1-C_{j}\right) \ln \operatorname{Pr}\left(D_{j}=S_{f j} \mid D_{j}>S_{0 j}\right)\right\}
\end{aligned}
$$

where $j$ indexes jobs and $c_{j}$ is an indicator variable that equals one if the completed job duration is censored and equals zero otherwise. ${ }^{18}$

16. See Lancaster (1979) for a parametric approach to the problem of estimating unmeasured heterogeneity in a Weibull model of unemployment duration. Heckman and singer (1984) present a semi-parametric approach to estimating duration models with unmeasured heterogeneity.

17. It is important to condition on the length of the job as of the date it is first observed because the sampling scheme is such that jobs will not be observed unless they last long enough to make it to the start of the sample
period.

18. Note that this specification of the likelihood function assumes that unmeasured factors affecting completed job durations are independent across spells. A more complete specification would recognize that we observe some people on more than one job and allow explicitly for individual heterogeneity in job changing propensity. Given the nonlinear nature of the model, we saw 


\section{Estimation of the Job Duration Model}

Column 1 and column 2 of Table 2 contain estimates of the Weibull job duration model estimated over the subsamples of 767 union blue collar jobs and 1417 nonunion blue collar jobs, respectively. These estimates were derived by maximizing the likelihood function defined above with respect to the parameters $\gamma$ and $\alpha .{ }^{19}$ In interpreting the estimates of the determinants of the baseline hazard $(\lambda)$, recall that the hazard rate was specified such that $\lambda=e^{-Z \gamma}$. Thus, an increase in a variable with a positive coefficient reduces $\lambda$ and increases the expected duration of the job. In both models the hypothesis that the all of the coefficients $(\gamma)$ in the baseline hazard $(\lambda)$ with the exception of the constant are zero can be rejected at any reasonable level of significance. 20 Thus, the variables included in the model have significant explanatory power for job duration.

The two sets of estimates are generally similar. In both the union and the nonunion sample, years of experience prior to taking a job has a positive effect on the completed duration of the job. Married workers jobs tend to last longer than those of otherwise similar workers. Education raises predicted job duration for the nonunion sample, but has no statistically significant effect on job duration for the union sample. Being a foreman or craft worker has a stronger effect on the duration of union jobs than on the duration of nonunion jobs.

no obvious appropriate and tractable way to do this.

19. The algorithm described by Berndt, Hall, Hall, and Hausman (1974) was used to find the maximum.

20. The likejihood ratio statistic is 81.2 for the union model. This is distributed as $x^{2}$ with 21 degrees of freedom. The likelihgod ratio statistic is 104.8 for the nonunion model. This is distributed as $x^{2}$ with 22 degrees of freedom. 
Table 2:

Selected Coefficients from Final Tenure Models ${ }^{a}$

\begin{tabular}{|c|c|c|}
\hline & $\begin{array}{c}(1) \\
\text { Union } \\
\text { Blue } \\
\text { Collar }\end{array}$ & $\begin{array}{c}(2) \\
\text { Nonunion } \\
\text { Blue } \\
\text { Collar }\end{array}$ \\
\hline \multicolumn{3}{|c|}{$\gamma$ (Inverse Baseline Hazard, $\lambda=e^{-z \gamma}$ ) } \\
\hline Years of experience & $\begin{array}{l}.0407 \\
(.0185)\end{array}$ & $(.0611)$ \\
\hline (Years of experience) $^{2}$ & $\begin{array}{l}-.00068 \\
(.00054)\end{array}$ & $\begin{array}{l}-.00113 \\
(.00027)\end{array}$ \\
\hline Years of education & $\begin{array}{c}.00235 \\
(.02366)\end{array}$ & $\begin{array}{l}.0243 \\
(.0136)\end{array}$ \\
\hline Nonwhite (yes $=1$ ) & $\begin{array}{l}.178 \\
(.171)\end{array}$ & $\begin{array}{c}-.0387 \\
(.0878)\end{array}$ \\
\hline Married (yes $=1$ ) & $\begin{array}{l}.271 \\
(.161)\end{array}$ & $\begin{array}{l}.464 \\
(.0730)\end{array}$ \\
\hline Disabled (yes $=1$ ) & $\begin{array}{l}-.512 \\
(.174)\end{array}$ & $\begin{array}{l}.180 \\
(.113)\end{array}$ \\
\hline Foreman, craftworker (yes = 1$)$ & $\begin{array}{l}.206 \\
(.116)\end{array}$ & $\begin{array}{l}.0656 \\
(.0623)\end{array}$ \\
\hline \multicolumn{3}{|l|}{ "Duration" Parameter } \\
\hline$\alpha$ & $\begin{array}{l}.356 \\
(.029)\end{array}$ & $\begin{array}{l}.394 \\
(.017)\end{array}$ \\
\hline \multirow[t]{2}{*}{ Log-Likelihood } & -702.5 & -1097.9 \\
\hline & 767 & 1417 \\
\hline
\end{tabular}




\section{Prediction of Job Duration for Incomplete Jobs}

We used the parameter estimates from the appropriate column of Table 2 to predict the expected completed job duration of each of the incomplete jobs in the two samples. 21 This expectation is computed conditionally on the job lasting longer than the last observed seniority $\left(S_{f}\right.$ years $)$. Note that the job duration model we have estimated is based on data for the pre-retirement period. It will capture the net effects of quit and layoff processes on job duration, but will not capture the effect of the competing retirement process which comes into play for older workers. If we predicted job durations without taking retirement into account, some would be implausibly long. We therefore assume that all jobs that are in progress when the worker reaches age 65 end at that point.

For an individual/job match with observable characteristics $z$ that has lasted $s_{f}$ years as of the last date we observe it, the conditional expected completed job duration is:

$$
\left.\hat{E}(D \mid D) S_{f}\right)=\frac{1}{\left.\operatorname{Pr}(D) S_{f}\right)} \int_{S_{f}}^{S_{65}} \lambda \alpha t^{\alpha} e^{-\lambda t^{\alpha}} d t+\frac{\operatorname{Pr}\left(D 2 S_{65}\right)}{\operatorname{Pr}\left(D 2 S_{f}\right)} \star S_{65}
$$

where $S_{65}$ represents the seniority attained if a match lasts until the worker turns 65 ,

$$
\begin{aligned}
& \operatorname{Pr}\left(D>S_{f}\right)=\exp \left[-\lambda S_{f}^{\alpha}\right], \\
& \operatorname{Pr}\left(D \geq S_{65}\right)=\exp \left[-\lambda S_{65}^{\alpha}\right], \text { and } \\
& \lambda=e^{-Z \gamma} .
\end{aligned}
$$

All predictions use the parameter estimates contained in Table 2. The conditional expectation of the square of completed job duration was computed in a similar manner.

21. Recall that the actual completed job duration is used for the completed jobs. 
Many of the union blue collar jobs were quite long; of the 767 completed and incomplete jobs represented in the sample, 22 percent were predicted to have completed durations of 1 year or less, 9 percent to have completed durations of 1 to 3 years, 17 percent to have completed durations of 3 to 10 years and 51 percent to have completed durations of more than ten years. More of the nonunion blue collar jobs were relatively short; of the 1417 completed and incomplete jobs represented in the sample, 35 percent were predicted to have completed durations of 1 year or less, 16 percent to have completed durations of 1 to 3 years, 25 percent to have completed durations of 3 to 10 years, and 24 percent to have completed durations of more than ten years.

\section{Earnings Function Estimates}

Having derived an estimate of completed job duration we turn now to the question of the relative magnitude of the net returns to seniority in union and nonunion jobs.

Our starting point is to fit standard earnings functions of the form

$$
\ln \left(w_{i j t}\right)=\theta_{0}+\theta_{1} s_{i j t}+\theta_{2} E_{i j t}+\theta_{3} E_{i j t}^{2}+x_{i j t}{ }^{\omega}+\varepsilon_{i j t}
$$

where $\ln (W)$ is the logarithm of real average hourly earnings, $s_{i j t}$ is seniority, $E_{i j t}$ is total experience, $x_{i j t}$ is a vector of other individual characteristics, and $\varepsilon_{i j t}$ represents unmeasured factors affecting earnings. The coefficient $\theta_{1}$ is the net return to seniority and corresponds to $\beta_{1}$ $\left(B_{2}+\alpha\right)$ in the model of section II. These earnings functions are fit using the individual-year observations from the two jobs samples discussed in section III. There are 3084 individual-year observations for workers in union blue collar jobs and 3554 individual-year observations for workers in nonunion biue collar jobs.

The first columns of tables $3 a$ and $3 b$ contain estimates of 
selected parameters of standard earnings functions. 22 Each equation also includes controls for education, race, marital status, disability, occupation, industry, region, and time. These estimates imply that the returns to seniority are larger for the nonunion blue collar sample than for the union blue collar sample. Among union workers, each additional year of seniority is associated with roughly a 1.0 percent increment to earnings; among nonunion workers, each additional year of seniority is associated with earnings that are 1.4 percent higher. The difference between the two estimated seniority coefficients is significant at better than the 0.01 level.

The instrumental variables estimates in the tables' second columns tell a very different story. In these equations, the residual from the regression of seniority on completed job duration is used as an instrument for seniority, and pre-job experience and its square are used as instruments for total experience and its square. ${ }^{23}$ The estimated return to seniority for the union sample falls only slightly, from 1.0 percent per year to just over 0.7 percent per year. The decline in the estimated return to seniority is much larger for the nonunion sample, a drop of more than a full percentage point from 1.4 percent to 0.3 percent per year, and the corrected estimate is not significantly different from zero. In contrast to the standard equations, these equations imply that the return to seniority for union blue collar

22. The standard errors presented are the "simple" standard errors computed from $\sigma^{2}\left(X^{\prime} X\right)$ for the OLS models and from $\sigma^{2}\left(Z^{\prime} X\right)$ for the IV models. These standard errors are not strictly appropriate for the estimation here because they do not account for the fact that the measure of completed job duration is predicted for the observations on censored jobs. Standard errors that are corrected both for this fact and for general heteroskedasticity were computed for a number of specifications. These were uniformly very close to the "simple" standard errors.

23. In the regression of seniority on completed job duration fit for the union sample, the constant term is -1.990 (standard error 0.206 ) and the job duration coefficient is $0.500(0.008)$. In the nonunion equation, the constant term is $-1.313(0.097)$ and the job duration coefficient is $0.550(0.005)$. 
Table 3a:

Selected Coefficients from In(average hourly earnings) Models ${ }^{a}$ Union Blue Collar Sample

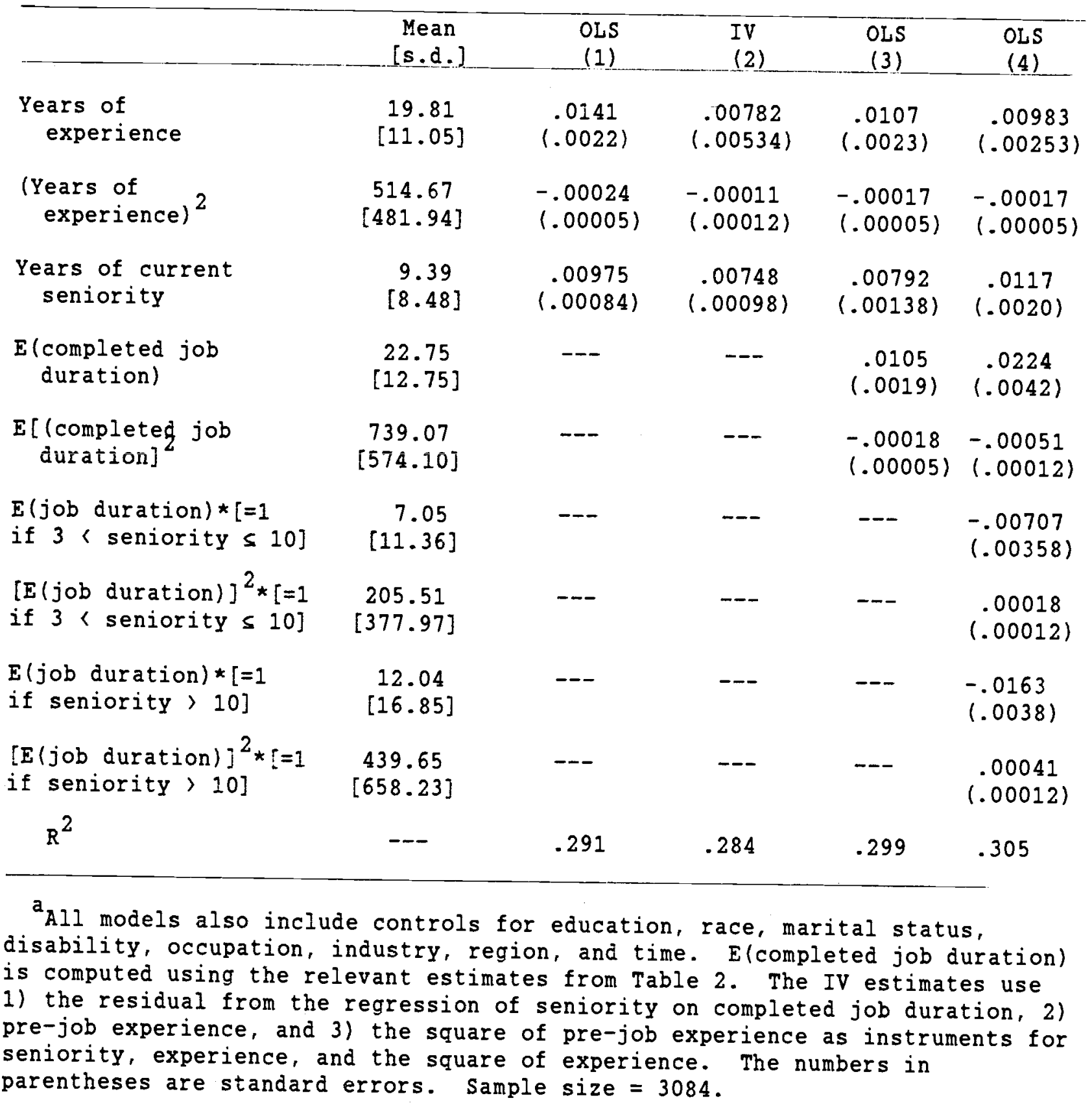


Table 3b:

Selected Coefficients from ln(average hourly earnings) Models ${ }^{a}$

Nonunion Blue Collar Sample

\begin{tabular}{|c|c|c|c|c|c|}
\hline & $\begin{array}{l}\text { Mean } \\
{[\text { s.d.] }}\end{array}$ & $\begin{array}{l}\text { OLS } \\
\text { (1) }\end{array}$ & $\begin{array}{l}\text { IV } \\
\text { (2) }\end{array}$ & $\begin{array}{l}\text { OLS } \\
\text { (3) }\end{array}$ & $\begin{array}{l}\text { OLS } \\
\text { (4) }\end{array}$ \\
\hline $\begin{array}{l}\text { Years of } \\
\text { experience }\end{array}$ & $\begin{array}{c}17.34 \\
{[11.14]}\end{array}$ & $\begin{array}{l}.0205 \\
(.0024)\end{array}$ & $\begin{array}{l}.0173 \\
(.0040)\end{array}$ & $\begin{array}{l}.0117 \\
(.0026)\end{array}$ & $\begin{array}{l}.0120 \\
(.0026)\end{array}$ \\
\hline $\begin{array}{l}\text { (Years of } \\
\quad \text { experience) }\end{array}$ & $\begin{array}{c}424.70 \\
{[470.81]}\end{array}$ & $\begin{array}{l}-.00045 \\
(.00006)\end{array}$ & $\begin{array}{l}-.00042 \\
(.00009)\end{array}$ & $\begin{array}{l}-.00026 \\
(.00006)\end{array}$ & $\begin{array}{l}-.00028 \\
(.00006)\end{array}$ \\
\hline $\begin{array}{l}\text { Years of current } \\
\text { seniority }\end{array}$ & $\begin{array}{c}6.31 \\
{[7.46]}\end{array}$ & $\begin{array}{l}.0142 \\
(.0011)\end{array}$ & $\begin{array}{l}.00290 \\
(.00172)\end{array}$ & $\begin{array}{l}.00241 \\
(.00213)\end{array}$ & $\begin{array}{l}-.00054 \\
(.00302)\end{array}$ \\
\hline $\begin{array}{l}E \text { (completed job } \\
\text { duration) }\end{array}$ & $\begin{array}{c}13.86 \\
{[11.75]}\end{array}$ & --- & -- & $\begin{array}{l}.0154 \\
(.0021)\end{array}$ & $\begin{array}{l}.0381 \\
(.0057)\end{array}$ \\
\hline $\begin{array}{l}E[\text { (completed job } \\
\text { duration }]\end{array}$ & $\begin{array}{c}362.44 \\
{[444.45]}\end{array}$ & --- & --- & $\begin{array}{l}-.00014 \\
(.00006)\end{array}$ & $\begin{array}{l}-.00104 \\
(.00024)\end{array}$ \\
\hline $\begin{array}{l}E(\text { job duration }) *[=1 \\
\text { if } 3 \text { (seniority } \leq 10]\end{array}$ & $\begin{array}{c}4.57 \\
{[8.27]}\end{array}$ & --- & -- & -- & $\begin{array}{l}-.00592 \\
(.00538)\end{array}$ \\
\hline $\begin{array}{l}{[E(j \circ b \text { duration })]^{2} \star[=1} \\
\text { if } 3 \text { ( seniority } \leq 10]\end{array}$ & $\begin{array}{r}102.13 \\
{[211.7]}\end{array}$ & -- & -- & -- & $\begin{array}{l}.00031 \\
(.00024)\end{array}$ \\
\hline $\begin{array}{l}E(\text { job duration }) *[=1 \\
\text { if seniority }>10]\end{array}$ & $\begin{array}{r}6.45 \\
{[12.90]}\end{array}$ & --- & -- & --- & $\begin{array}{l}-.0241 \\
(.0055)\end{array}$ \\
\hline $\begin{array}{l}{[E(\text { job duration })]^{2} \star[=1} \\
\text { if seniority }>10]\end{array}$ & $\begin{array}{c}215.1 \\
{[461.9]}\end{array}$ & --- & --- & -- & $\begin{array}{l}.00103 \\
(.00024)\end{array}$ \\
\hline$R^{2}$ & -- & .388 & .351 & .404 & .410 \\
\hline
\end{tabular}

${ }^{a}$ AIl models also include controls for education, race, marital status, disability, occupation, industry, region, and time. E(completed job duration) is computed using the relevant estimates from Table 2. The IV estimates use 1) the residual from the regression of seniority on completed job duration, 2) pre-job experience, and 3) the square of pre-job experience as instruments for seniority, experience, and the square of experience. The numbers in parentheses are standard errors. Sample size $=3554$. 
workers is larger than the return for nonunion blue collar workers, a difference that is significant at better than the 0.01 level.

As discussed earlier, an alternative estimate of the net return to seniority can be obtained by adding completed job duration to the standard earnings function. This is done in the column (3) models of tables $3 a$ and $3 b$. The returns to seniority estimated using this alternative approach are virtually identical to those obtained using the IV approach. While the theoretical discussion in Section II implied that the augmented oLs estimates of the return to seniority reported in column (3) may be upward biased, the close correspondence between the IV and augmented OLS estimates indicates that any such bias is small. 24

These findings are in accord with some scattered earlier results. Mincer (1983) finds that controlling for prior mobility reduces the estimated return to seniority for nonunion workers, but not for union workers. Altonji and Shakotko (1987) use an instrumental variables approach to dealing with the bias in estimated returns to seniority. While union/nonunion differences are not a central focus of their study, they do report that their correction procedure reduces the estimated return to seniority more dramatically for nonunion workers than for union workers.

The other interesting implication of the column (3) estimates is that, in both samples, those on long jobs earn substantially and significantly more than those on short jobs. Among union blue collar workers, someone on a job that will end up lasting twenty years earns 9.0 percent more in each year on the job than someone on a job that will end up lasting only five years. Among nonunion blue collar workers, someone on a twenty year job earns approximately

24. In fact, in the nonunion sample, the augmented ols estimate is slightly, though not significantly, smaller than the IV estimate. 
18 percent more in each year on the job than someone on a five year job.

In the column (4) models, we allow the effects of completed job duration to vary with current seniority. The results confirm that those on long jobs earn more at all points on the job, although the effect seems to be strongest at the start of the job and somewhat weaker later on.

The column (4) results contradict one possible alternative interpretation of our central finding that, when completed job duration is introduced into the earnings equation, it takes on a positive coefficient and the estimated return to seniority falls. Specifically, it might be argued that the returns to seniority are higher on long jobs than on short jobs and that, because we do not allow for this possibility, completed job duration enters with a positive coefficient and soaks up some of what are in fact returns to seniority. If this interpretation were correct, when we allowed the effects of completed job duration to vary with current seniority, we should find that eventual completed job duration is only weakly associated with earnings among workers with lower levels of seniority, and more strongly associated with earnings among workers with higher levels of seniority. In fact, the opposite appears to be true.

Probably the most important question to be raised about the preceding analysis is whether we have done a sufficiently good job of measuring completed job duration. Using expected completed job duration in place of actual completed job duration does not cause inconsistency in the earnings equation parameter estimates, provided the correct job duration model has been used in computing completed job duration. However, if the job duration model itself is misspecified and this leads to random errors in the expected completed job duration variable, both the instrumental variables estimate and 
the augmented OLS estimate of the return to seniority are biased upwards. 25

In the present context, if we have done a less good job of predicting expected completed job duration for the union blue collar sample than for the nonunion blue collar sample, this could at least in part account for the higher estimated return to seniority for union workers than for nonunion workers in the IV and augmented ous equations.

In light of this concern, we have made an effort to assess the method used to compute completed job durations for the censored jobs. Since our measure of completed job duration for censored jobs is really a nonlinear transformation of the sorts of variables already included in the earnings function plus the last observed value of seniority, an obvious question is whether our measure completed job duration contains information beyond that contained in last observed seniority itself. The models in the first three columns of tables $4 \mathrm{a}$ and $4 \mathrm{~b}$ indicate that, for both the union and the nonunion samples, this question can be answered "yes". For comparison, column (1) repeats the augmented ous equation that includes completed job duration and its square. In column (2), last observed seniority and its square replace completed job duration. The column (3) models include both completed job duration and last observed seniority. In both samples, comparison of column (2) and column (3) reveals that the inclusion of completed job duration and

25. Taking the instrumental variables approach, the instrument for seniority is constructed as the residual from the regression of seniority on expected completed job duration. If there are random errors in the expected completed job duration variable, its coefficient in this regression will be biased downward. This means that the constructed residual will be positively correlated with actual completed job duration and thence with omitted individual or job/match quality. Using this residual as an instrument for seniority in the earnings equation yields an upward biased estimate of the return to seniority. In the augmented ols earnings equation, random errors in the expected completed job duration variable cause the job duration coefficient to be biased towards zero and the estimated net return to seniority to be biased upwaras. 
Table 4a:

Selected Coefficients from in (average hourly earnings) Models Union Blue Collar Sample

Alternative Models

\begin{tabular}{|c|c|c|c|c|c|}
\hline & $\begin{array}{l}\text { Mean } \\
\text { [s.d.] }\end{array}$ & $\begin{array}{l}\text { OLS } \\
\text { (1) }\end{array}$ & $\begin{array}{l}\text { OLS } \\
(2) \\
\end{array}$ & $\begin{array}{l}\text { OLS } \\
\text { (3) }\end{array}$ & $\begin{array}{l}\text { OLS } \\
(4) \\
\end{array}$ \\
\hline $\begin{array}{l}\text { Years of } \\
\text { experience }\end{array}$ & $\begin{array}{c}19.81 \\
{[11.05]}\end{array}$ & $\begin{array}{l}.0107 \\
(.0023)\end{array}$ & $\begin{array}{l}.0101 \\
(.0023)\end{array}$ & $\begin{array}{l}.00996 \\
(.00232)\end{array}$ & $\begin{array}{l}.00896 \\
(.00235)\end{array}$ \\
\hline $\begin{array}{l}\text { (Years of } \\
\quad \text { experience) }\end{array}$ & $\begin{array}{c}514.67 \\
{[481.94]}\end{array}$ & $\begin{array}{l}-.00017 \\
(.00005)\end{array}$ & $\begin{array}{l}-.00013 \\
(.00005)\end{array}$ & $\begin{array}{l}-.00016 \\
(.00005)\end{array}$ & $\begin{array}{l}-.00010 \\
(.00005)\end{array}$ \\
\hline $\begin{array}{c}\text { Years of current } \\
\text { seniority }\end{array}$ & $\begin{array}{c}9.39 \\
{[8.48]}\end{array}$ & $\begin{array}{l}.00792 \\
(.00138)\end{array}$ & $\begin{array}{l}-.00251 \\
(.00257)\end{array}$ & $\begin{array}{l}-.00104 \\
(.00287)\end{array}$ & $\begin{array}{l}.00371 \\
(.00183)\end{array}$ \\
\hline $\begin{array}{c}\text { E(completed job } \\
\text { duration) }\end{array}$ & $\begin{array}{c}22.75 \\
{[12.75]}\end{array}$ & $\begin{array}{l}.0105 \\
(.0019)\end{array}$ & -- & $\begin{array}{l}.00701 \\
(.00329)\end{array}$ & $\begin{array}{l}.00950 \\
(.00284)\end{array}$ \\
\hline $\begin{array}{c}\left\{\mathrm{E}\left(\text { completed } j \mathrm{~g}^{b}\right.\right. \\
\text { duration })\}\end{array}$ & $\begin{array}{c}739.07 \\
{[574.10]}\end{array}$ & $\begin{array}{l}-.00018 \\
(.00005)\end{array}$ & --- & $\begin{array}{l}-.00017 \\
(.00007)\end{array}$ & $\begin{array}{l}-.00009 \\
(.00005)\end{array}$ \\
\hline $\begin{array}{l}\text { Years Last Observed } \\
\text { Seniority }\end{array}$ & $\begin{array}{l}12.86 \\
{[9.53]}\end{array}$ & -- & $\begin{array}{l}.0176 \\
(.0027))\end{array}$ & $\begin{array}{l}.0120 \\
(.0050)\end{array}$ & -- \\
\hline $\begin{array}{l}\text { Years Last observed } \\
\text { Seniority } 2\end{array}$ & $\begin{array}{l}256.15 \\
{[316.41]}\end{array}$ & --- & $\begin{array}{l}-.00018 \\
(.00006)\end{array}$ & $\begin{array}{l}-.00001 \\
(.00009)\end{array}$ & --- \\
\hline $\begin{array}{l}E(\text { job duration }) *[=1 \\
\text { if uncensored }]\end{array}$ & {$\left[\begin{array}{l}1.53 \\
4.24]\end{array}\right.$} & --- & -- & --- & $\begin{array}{l}.01409 \\
(.00482)\end{array}$ \\
\hline $\begin{array}{l}\{E(j o b \text { duration })\}^{2} \star \\
{[=1 \text { if uncensored }]}\end{array}$ & $\begin{array}{c}20.35 \\
{[80.99]}\end{array}$ & --- & -- & --- & $\begin{array}{l}-.00043 \\
(.00022)\end{array}$ \\
\hline $\mathrm{R}^{2}$ & -- & .299 & .301 & .302 & .302 \\
\hline
\end{tabular}

all models also include controls for education, race, marital status, disability, occupation, industry, region, and year. E(completed job duration) is computed using the estimates in column (1) of table 2 . The numbers in parentheses are standard errors. Sample size $=3084$. 
Table 4b:

Selected Coefficients from In (average hourly earnings) Models Nonunion Blue Collar Sample

Alternative Models

\begin{tabular}{|c|c|c|c|c|c|}
\hline & $\begin{array}{c}\text { Mean } \\
\text { [s.d.] }\end{array}$ & $\begin{array}{l}\text { OLS } \\
\text { (1) }\end{array}$ & $\begin{array}{l}\text { OLS } \\
(2)\end{array}$ & $\begin{array}{l}\text { OLS } \\
\text { (3) } \\
\end{array}$ & $\begin{array}{l}\text { OLS } \\
(4)\end{array}$ \\
\hline $\begin{array}{l}\text { Years of } \\
\text { experience }\end{array}$ & $\begin{array}{c}17.34 \\
{[11.14]}\end{array}$ & $\begin{array}{l}.0117 \\
(.0026)\end{array}$ & $\begin{array}{l}.0135 \\
(.00256)\end{array}$ & $\begin{array}{l}.0118 \\
(.00259)\end{array}$ & $\begin{array}{l}.0119 \\
(.0027)\end{array}$ \\
\hline $\begin{array}{l}\text { (Years of } \\
\quad \text { experience) }\end{array}$ & $\begin{array}{c}424.70 \\
{[470.81]}\end{array}$ & $-.00026)$ & $\begin{array}{l}-.00028 \\
(.00006)\end{array}$ & $\begin{array}{l}-.00026 \\
(.00006)\end{array}$ & $\begin{array}{l}-.00027 \\
(.00006)\end{array}$ \\
\hline $\begin{array}{c}\text { Years of current } \\
\text { seniority }\end{array}$ & $\begin{array}{c}6.31 \\
{[7.46]}\end{array}$ & $\begin{array}{l}.00241 \\
(.00213)\end{array}$ & $\begin{array}{l}-.00304 \\
(.00322)\end{array}$ & $\begin{array}{l}.00375 \\
(.00352)\end{array}$ & $\begin{array}{l}.00412 \\
(.00307)\end{array}$ \\
\hline $\begin{array}{c}\text { E(completed job } \\
\text { duration) }\end{array}$ & $\begin{array}{c}13.86 \\
{[11.75]}\end{array}$ & $\begin{array}{l}.0154 \\
(.0021)\end{array}$ & --- & $\begin{array}{l}.0175 \\
(.0052)\end{array}$ & $\begin{array}{l}.0167 \\
(.0022)\end{array}$ \\
\hline $\begin{array}{c}\text { E(completed job } \\
\text { duration) }\}^{2^{b}}\end{array}$ & $\begin{array}{c}362.44 \\
{[444.45]}\end{array}$ & $\begin{array}{l}-.00014 \\
(.00006)\end{array}$ & --- & $\begin{array}{l}-.00017 \\
(.00012)\end{array}$ & $\begin{array}{l}-.00020 \\
(.00008)\end{array}$ \\
\hline $\begin{array}{l}\text { Years Last Observed } \\
\text { Seniority }\end{array}$ & $\begin{array}{l}8.80 \\
{[8.82]}\end{array}$ & -- & $\begin{array}{l}.0255 \\
(.0031)\end{array}$ & $\begin{array}{l}-.00377 \\
(.00730)\end{array}$ & --- \\
\hline $\begin{array}{l}\text { \{Years Last Qbserved } \\
\text { Seniority\} }\end{array}$ & $\begin{array}{c}155.2 \\
{[263.8]}\end{array}$ & -- & $\begin{array}{l}-.00031 \\
(.00008)\end{array}$ & $\begin{array}{l}.00005 \\
(.00017)\end{array}$ & -- \\
\hline $\begin{array}{c}E(j o b \text { duration }) \star[=1 \\
\text { if uncensored }]\end{array}$ & {$\left[\begin{array}{l}1.29 \\
3.39]\end{array}\right.$} & -- & -- & -- & $\begin{array}{l}.00556 \\
(.00627)\end{array}$ \\
\hline $\begin{array}{l}\{E(\text { job duration })\}^{2} \star \\
\quad[=1 \text { if uncensored }]\end{array}$ & $\begin{array}{c}13.18 \\
{[60.21]}\end{array}$ & -- & --- & --- & $\begin{array}{l}-.00053 \\
(.00030)\end{array}$ \\
\hline $\mathrm{R}^{2}$ & -- & .4041 & .4001 & .4042 & .4051 \\
\hline
\end{tabular}

all models also include controls for education, race, marital status, aisability, occupation, industry, region, and year. E(completed job duration) is computed using the estimates in column (2) of table 2. The numbers in parentheses are standard errors. Sample size $=3554$. 
its square adds significantly to the model's explanatory power at the 0.05 level or better, even after controlling for last observed seniority. The major difference between the two samples is that last observed seniority adòs significantly to the explanatory power of the union model even after completed job duration has been controlled for, whereas it does not add significantly to the explanatory power of the nonunion model. ${ }^{26}$ We have no explanation for why last observed seniority should have an independent association with earnings in the union sector.

Another obvious question concerning our completed job duration variable is whether the relationship between completed job duration and earnings differs between the observations that come from jobs where actual completed durations are observed and from jobs where completed durations are predicted. To answer this question, we reestimated the augmented ols earnings functions with two additional variables: the interaction between completed job duration with a cummy variable that equals one if the job duration is uncensored and equals zero otherwise, and the interaction of the square of completed job duration with the same cummy variable. These estimates are contained in column (4) of tables $4 a$ and $4 b$. In the union sample, these interaction terms add significantly to the explanatory power of the model; in the nonunion

26. This is verified by $F$-tests of the general specification in column (3) against the restricted specifications in column (1) and column (2). The test statistics for the hypothesis that completed job duration and its square have zero coefficients are 3.27 for union blue collar workers and 12.1 for nonunion blue collar workers. The test statistics for the hypothesis that last observed seniority and its square have zero coefficients are 6.22 for union blue collar workers and 0.295 for nonunion blue collar workers. All the test statistics are distributed as $F$ with 2 and approximately 3000 degrees of freedom. The critical values of this distribution are 3.00 at the 5 percent level and 4.61 at the 1 percent level. 
sample, they do not. 27

It is clear that our measure of completed job duration captures important variation in worker/job/match quality in both sectors. However, our procedures do seem to be somewhat more satisfactory for the nonunion sector than for the union sector. With regard to the estimated returns to seniority, the estimates in tables $4 a$ and $4 b$ imply roughly equal returns for union and nonunion workers, but these estimates are based on specifications with no obvious structural interpretation.

In conclusion, our corrected estimates (in tables $3 a$ and $3 b$ ) have the clear implication that the return to seniority in the union sector is larger than the return to seniority in the nonunion sector. This finding is conditional on our measures of union and nonunion job durations, and we do find some evidence that our union job duration measure is imperfect. However, even our explorations using iess restrictive models (in tables $4 \mathrm{a}$ and $4 \mathrm{~b}$ ) always yield estimated seniority coefficients in the union sector that are at least as large as the estimated nonunion seniority coefficients. Thus, we reject the standard finding that the return to seniority is smaller in the union sector than in the nonunion sector.

27. The test statistics are 6.22 for the union sample and 2.95 for the nonunion sample, both distributed as $F$ with 2 and just over 3000 degrees of freedom. The critical values of this distribution are 3.00 at the 5 percent level and 4.61 at the 1 percent level. 


\section{REFERENCES}

Abowd, John M. and Henry S. Farber, "Job Queues and the Union Status of Workers," Industrial and Labor Relations Review, Vol. 35, No. 3 (April 1982).

Abraham, Katharine G. and Henry S. Farber, "Job Duration, Seniority, and Earnings," American Economic Review, Vol. 77, No. 3 (June 1987), pp. 278297.

Abraham, Katharine G. and James L. Medoff, "Length of Service and Layoffs in Union and Nonunion Work Groups," Industrial and Labor Relations Review, vol. 38, No. 1 (October 1984), pp. 87-97.

Abraham, Katharine G. and James L. Medoff, "Length of Service and Promotions in Union and Nonunion Work Groups," Industrial and Labor Relations Review, Vol. 38, No. 3 (April 1985), pp. 408-420.

Altonji, Joseph, and Robert Shakotko, "Do Wages Rise with Job Seniority?", Review of Economic Studies, Vol. LIV, No. 179 (July 1987), pp. 437-459.

Berndt, E. K., B. H. Hall, R. E. Hall, and J. A. Hausman, "Estimation and Inference in Nonlinear Structural Models," Annals of Economic and Social Measurement 3/4, 1974, pp. 653-665.

D. Blajr and D. Crawford, "Labor Union Objectives and Collective Bargaining," Quarterly Journal of Economics (August 1984):547-566.

Bloch, Farrell E. and Mark S. Kuskin. "Wage Determination in the Union and Nonunion Sectors," Industrial and Labor Relations Review 31, no. 2 (January 1978): 183-92.

Borjas, George J., "Job Satisfaction, Wages, and Unions," Journal of Human Resources, Winter 1979, pp. 568-577, pp. 1-40.

Farber, Henry S. "Individual Preferences and Union Wage Determination: The Case of the United Mine Workers," Journal of Political Economy 86 (October 1978): 923-42.(b)

FarDer, Henry S. "The Determination of the Union Status of Workers," Econometrica 51, no. 5. (September 1983): 1417-1437. (a)

Farber, Henry S. "Worker Preferences for Union Representation," Research in Labor Economics, Supplement 2 (1983): 171-205.(b)

Farber, Henry S. "The Analysis of Union Behavior." Working Paper No. 1502, National Bureau of Economic Research, October 1984. Forthcoming in The Hancbook of Labor Economics, North Holland Publishing Company.

Freeman, Richard B., "Unionism and the Dispersion of Wages," Industrial and Labor Relations Review, Vol 34, No. 1 (October 1980), pp. 3-23.

Freeman, Richard B., "Union Wage Practices and Wage Dispersion Within Establishments," Industrial and Labor Relations Review, Vol. 36, No. 1 (October 1982), pp. 3-21. 
Freeman, Richard B. and James I. Medoff, What Do Unions Do?, New York: Basic Books, Inc., 1984.

Gersuny, Carl, "Employment Seniority and Distributive Justice," mimeo, 1981.

Hall, Robert E., "The Importance of Lifetime Jobs in the U.S. Economy," American Economic Review, September 1982, pp. 315-333.

Heckman, J. and B. Singer, "A Method for Minimizing the Impact of Distributional Assumptions in Econometric Models for Duration Data," Econometrica 52, March 1984, pp. 271-320.

Hirsch, Barry T., "The Interindustry Structure of Unionism, Earnings and Earnings Dispersion," Industrial and Labor Relations Review, Vol. 36, No. 1 (October 1982), pp. 22-39.

Hyclak, Thomas, "The Effect of Unions on Earnings Inequality in Local Labor Markets," Industrial and Labor Relations Review, Vol. 33, No. 1 (October 1979), pp. 77-84.

Lancaster, Tony, "Econometric Methods for the Duration of Unemployment," Econometrica, July 1979, pp. 939-956.

Leigh, Duane, "Racial Discrimination and Labor Unions: Evidence from the NLS Sample of Middle-Aged Men," The Journal of Human Resources, Fall 1978.

Lewis, H. Gregg, Union Relative Wage Effects: A Survey, Chicago: University of Chicago Press, 1986.

Mellow, Wesley, "Employer Size, Unionism and Wages," in Research in Labor Economics, Supplement 2: New Approaches to Labor Unions, Joseph D. Reid, Jr., ed., Greenwich, Connecticut: JAI Press, 1983, pp. 253-282.

Pfeffer, Jeffrey, and Jerry Ross, "Union-Nonunion Effects on Wage and Status Attainment," Industrial Relations, Vol. 19, No. 2 (Spring 1980), pp. 140151 .

Polachek, Solomon W., "Unionization of White Collar Workers," mimeo, September 1983.

Slichter, Sumner H., Union Policies and Industrial Management, Washington: The Brookings Institution, 1941.

Slichter, Sumner H., James J. Healy, E. Robert Iivernash, The Impact of Collective Bargaining on Management, Washington: The Brookings Institution, 1960.

Topel, Robert, "Job Mobility, Search and Earnings Growth: A Reinterpretation of Human Capital Earnings Functions", in Ronald G. Ehrenberg, ed., Research in Labor Economics, Vol. 8, 1986, pp. 199-223.

Webb, Sidney and Beatrice Webb, Industrial Democracy. New York: Kelley, 1965 (reprint of 1920 ed.). 